\title{
Rebutting Four Arguments in Favour of Resolving ius cogens Norm Conflicts by Means of Proportionality Tests
}

\author{
Valentin Jeutner \\ Faculty of Law, Lund University, Lund, Sweden \\ valentin.jeutner@jur.lu.se
}

\begin{abstract}
The text casts doubt on the utility of proportionality tests to resolve conflicts between peremptory norms of public international law with reference to an argument advanced by João Ernesto Christófolo. Responding to Christófolo, the text maintains that subjecting conflicts between peremptory norms to a proportionality analysis entails judicial law-making, does not safeguard the interests protected by peremptory norms and that the use of proportionality tests cannot be justified with reference to the desired completeness of international law. Instead, the text argues that conflicts between peremptory norms should be dealt with head-on by openly acknowledging the existence of an irresolvable norm conflict and that, if at all, proportionality tests must be applied with utmost care to avoid that the interests of those undertaking a proportionality analysis prevail over the interests of those whose interests the balanced norms in questions are intended to protect.
\end{abstract}

\section{Keywords}

proportionality - ius cogens - irresolvable norm conflicts

This contribution investigates and calls into question the utility of proportionality tests to resolve conflicts between peremptory norms of public international law. The contribution's point of departure is the argument, recently 
advanced by João Ernesto Christófolo, ${ }^{1}$ that proportionality tests are a suitable tool to address conflicts between ius cogens norms "when there are no other applicable and adequate rules for solving” 2 them. Christófolo's argument in favour of proportionality as a tool to resolve ius cogens norm conflicts essentially consists of two steps. In the first step, two assumptions are advanced: first, that ius cogens norm conflicts are possible, and, second, that international law's traditional norm conflict resolution principles are unable to resolve them. The second step involves the substantive argument in favour of proportionality in response to the shortcomings of international law's traditional norm conflict resolution mechanisms. Here Christófolo argues that proportionality is particularly well-suited to address ius cogens norm conflicts since it avoids judicial law-making, protects international law's integrity, and safeguards the interests ius cogens norms protect.

The first part below considers the argument's first step and establishes the accuracy of the observation that ius cogens norm conflicts cannot be resolved by means of international law's traditional norm conflict resolution principles. The second part, however, then proceeds to cast doubt on the substantive arguments in favour of proportionality. It will be argued that subjecting conflicting ius cogens norms to a proportionality analysis necessarily entails judicial law-making, that proportionality does not necessarily safeguard the interests protected by ius cogens norms and that subjecting ius cogens norm conflicts to a proportionality analysis cannot be justified with reference to the desired completeness of international law. In light of these findings, the concluding part will then argue that ius cogens norm conflicts should be dealt with head-on, even at the expense of admitting that international law's ability to resolve norm conflicts is not unlimited. As will become apparent, the underlying reason for this position is that proportionality tests are frequently used to establish compromises between interests of paramount importance to the international legal order and its subjects. Accordingly, proportionality tests must be applied with utmost care to avoid any undue infringement of those interests. In particular, it must be ensured that the application of supposedly objective proportionality tests does not lead to situations where the interests of those undertaking a proportionality analysis prevail over the interests of those whose interests the balanced norms in questions are intended to protect.

1 J.E. Christófolo, Solving Antinomies between Peremptory Norms in Public International Law (Schulthess, Zurich, 2016).

2 Ibid., p. 57. 
This section considers two questions that precede any analysis of proportionality's competence to resolve conflicts between ius cogens norms. Namely, can ius cogens norms conflict and, if yes, why could such conflicts not be addressed by international law's traditional norm conflict resolution principles?

A precondition for being able to answer the first question is a working definition of norm conflict. While there are various definitions of norm conflicts in international law, ${ }^{3}$ for the purposes of considering the utility of a proportionality analysis to resolve conflicts between ius cogens norms, it is proposed that a conflict between two or more ius cogens norms exists when, after a harmonious interpretation of the norms concerned has been attempted, the application of one norm leads to the impairment of the other. ${ }^{4} \mathrm{~A}$ norm is impaired, in this context, if the application of a conflicting norm A deprives conflicting norm B of the effect the norm creators of norm B intended norm B to have. ${ }^{5}$

While conflicts of this kind can and do arise frequently between norms in a legal order that is as fragmented as international law, ${ }^{6}$ the International Law Commission (ILC) also explicitly considered the possibility of conflicts of this kind arising between two or more ius cogens norms in early drafts of the ILC's work on the Articles on the Responsibility of States for Internationally Wrongful Acts. ${ }^{7}$ Of course, it might be "difficult to believe that the international legal order could admit at the same time of a peremptory norm of general international law prohibiting the fulfilment of an obligation or the exercise of a right, and another peremptory norm authorising the same fulfilment or exercise". ${ }^{8}$ Indeed, it is

3 See, for example, E. Vranes, "The Definition of "Norm Conflict" in International Law and Legal Theory', 17 European Journal of International Law (2006) p. 395; A. Verdross, 'Eine Antinomie der Rechtstheorie', in H.R. Klecatsky (ed.), Die Wiener rechtstheoretische Schule (Franz Steiner, Stuttgart, 2010); C.W. Jenks, 'The Conflict of Law-Making Treaties', 3 o British Year Book of International Law (1953) p. 401. While Christófolo himself adopts a broader definition of conflict (Christófolo, supra note 1, p. 15), his definition also extends to the cases captured by the definition presented here.

4 For a significantly more nuanced definition of norm conflict in the sphere of international law, see V. Jeutner, Irresolvable Norm Conflicts in International Law: The Concept of a Legal Dilemma (Oxford University Press, Oxford, 2017) p. 20.

5 J. Pauwelyn, Conflict of Norms in Public International Law (Cambridge University Press, Cambridge, 2003) pp. 251, 273.

6 On the fragmented nature of international law, see generally M. Koskenniemi, Fragmentation of International Law: Difficulties Arising from the Diversifications and Expansion of International Law - Report of the Study Group of the ILC (UN Doc A/CN.4/L.682) (2006).

7 W. Riphagen, Third Report on the Content, Forms and Degrees of International Responsibility (Part Two of the Draft Articles) (UN Doc A/CN.4/354 and Corr.1 and Add.1 \& 2) (1982) p. 47.

8 United Nations General Assembly, Sixth Committee, Summary Records of Meetings (16 November 1982) (UN Doc A/C.6/37/SR.46) para. 109 (Comment of delegate Razanakoto (Madagascar)). 
highly unlikely that an "intrinsic norm conflict", ${ }^{9}$ where two ius cogens norms are necessarily in conflict regardless of any factual contingencies, emerges in international law. However, it is not unthinkable that circumstances could arise that would set two otherwise harmonious ius cogens norms on a collision course. Such a situation could exist if a genocide could be prevented only by means of a "counter-genocide" (admittedly a far-fetched example, but one taken directly from the ILC's Commentary on the Draft Articles on the Responsibility of States for Internationally Wrongful Acts). ${ }^{10}$ According to Kolb, a ius cogens conflict could emerge between the "peremptory non-use of force and peremptory fundamental human rights",11 and Christófolo argues that there could be a norm conflict between two ius cogens norms with respect to the conflict between "the peremptory prohibition of the territorial acquisition by forcible means as a corollary of the peremptory prohibition of the use of force" and "the peremptory right of the Palestinian people to self-determination.". ${ }^{2}$ While it is not uncontroversial whether these cases are ius cogens norm conflicts, for now it shall be assumed for the sake of testing the argument that they are.

If it is the case that ius cogens norms can conflict, the next question is how international law could respond to conflicts of this kind in a way that ensures all relevant legal interests are adequately taken into account. By default, one could attempt to address such conflicts by means of international law's conventional norm conflict resolution principles, lex specialis, lex posterior and lex superior. Between conflicting norms, these principles establish a hierarchy in favour of the most specific norm (lex specialis), the latest norm (lex posterior) or the norm of highest rank (lex superior). In many situations, resort to these principles can resolve an otherwise existing genuine norm conflict. However, as Christófolo rightly submits, ${ }^{13}$ there can be situations ${ }^{14}$ when conflicting norms cannot be distinguished based on their specificity (lex specialis), time of creation (lex posterior) or rank (lex superior).

9 Jeutner, supra note 4, p. 31.

10 ILC, Commentary to the ILC Articles on Responsibility of States for Internationally Wrongful Acts (ILC Ybk 2001/II(2) 31) art. 26[4].

11 R. Kolb, Peremptory International Law - Jus Cogens: A General Inventory (Bloomsbury Publishing, London, 2015) p. 121.

12 Christófolo, supra note 1, p. 306.

13 Ibid., p. 38.

14 Christófolo refers to such situations as 'hard cases' (ibid., p. 38. See also D. Pulkowski, The Law and Politics of International Regime Conflict (Oxford University Press, Oxford, 2014) p. 344). However, this can be misleading since the term "hard cases" traditionally refers to provisions that are vague or non-existent (R. Dworkin, 'Hard Cases', 88 Harvard Law Review (1975) pp. 1057, 1058) or that exist within legal rule's "penumbra of uncertainty" (HLA Hart, The Concept of Law (2nd edn., Clarendon Press, Oxford, 1994) p. 12). 
Indeed, if any of the three indicators is the same (for example, when two conflicting norms originate from the same legal instrument) ${ }^{15}$ or unknown, the application of these traditional mechanisms is going to be difficult. Likewise, there can be situations when the respective indicators are irrelevant - namely when, with respect to the lex superior principle, two norms of the highest rank collide. In domestic law, this can be the case when two constitutional norms conflict, for example. In such circumstances, constitutional norm A can (normally) not be prioritised over constitutional norm B. ${ }^{16}$ In international law, this is the case when two ius cogens norms conflict.

In light of the limited ability of international law's traditional mechanisms to resolve conflicts between ius cogens norms, Christófolo suggests that one solution might be to "balance" and "weigh" the conflicting norms in accordance with the principles governing proportionality tests in domestic law. ${ }^{17}$ Adopting the "classic"18 three-part approach to proportionality, Christófolo explains that a proportionality test entails a determination of suitability, necessity and proportionality strictu sensu..$^{19}$ This means norm conflicts should be resolved in a manner that avoids "that measures incapable of achieving the pursued objective encroach on a countervailing and equally valid principle", ${ }^{20}$ "that the means employed to achieve the objective pursued by one principle be the least intrusive with regard to the countervailing principle, ${ }^{21}$ and that it should be considered whether a "measure should be chosen at all in order to pursue a certain objective". 22

Essentially, judges attempting to resolve a norm conflict between two ius cogens norms should resort to proportionality, which, Christófolo argues, has acquired the status of a "general principle of international law". ${ }^{23}$ Judges

15 The potential conflict between articles $1(1)$ and $1(2)$ of the 1922 Submarine Treaty might be an example of such a conflict. See Treaty relating to the Use of Submarines and Noxious Gases in Warfare (1922) 25 LNTS 202.

Christófolo provides the example of a conflict where one constitutional norm prohibits racist hate speech and where another constitutional norm guarantees the freedom of speech. See Christófolo, supra note 1, p. 39.

17 Ibid., p. 46.

18 I. Porat, 'Proportionality', Max Planck Encyclopedia of Comparative Constitutional Law (Oxford University Press, Oxford, 2018), https://oxcon.ouplaw.com, visited 10 March 2019; see also A. Barak, Proportionality: Constitutional Rights and Their Limitations (Cambridge University Press, Cambridge, 2012) p. 3.

19 Christófolo, supra note 1, pp. 47-48.

20 Ibid., p 47.

21 Ibid.

22 Ibid., p. 48.

23 Ibid., p. $5^{2}$. 
should do so in order to "determine which aspects of both conflicting norms should have more weight than others when dealing with a particular case". ${ }^{4}$ The overall objective of employing proportionality in this context is both to "solve alleged conflicts" and to "optimiz[e] commands emanating from countervailing principles". ${ }^{25}$ In essence, the aim of applying proportionality tests in such situations is to protect the integrity of all relevant legal norms and of all affected interests to the greatest possible extent.

Christófolo's conviction that proportionality tests are able to achieve this aim in the context of ius cogens norm conflicts relies on at least four arguments that will be scrutinised below.

\section{3 \\ Rebutting Four Arguments in Favour of the Omnipotence of Proportionality}

Christófolo's argument that proportionality is a suitable tool to address ius cogens norm conflicts presupposes that ius cogens norms are essentially legal principles (a), that proportionality avoids judicial law-making (b), that proportionality tests ensure that the interests that both conflicting norms protect are safeguarded (c), and that proportionality safeguards the integrity and completeness of the legal system (d). This section will scrutinise each of these arguments and show that although proportionality's benefits are manifold, there are norm conflicts that proportionality tests cannot resolve.

\subsection{Ius cogens Norms Are Not Necessarily Principles}

Christófolo's argument in favour of using proportionality to resolve conflicts between ius cogens norms explicitly relies on the domestic notion of proportionality developed by Robert Alexy. ${ }^{26}$ Alexy's theory of proportionality is in turn limited in scope to the resolution of conflicts between legal principles as opposed to legal rules. ${ }^{27}$ Indeed, Alexy makes it very clear that proportionality is of no assistance when it comes to the resolution of conflicts between legal rules. ${ }^{28}$ Accordingly, Christófolo must and does argue that ius cogens norms "can be compared to the function of principles in a given legal system". 29

24 Ibid., p. 47.

25 Ibid.

26 Ibid., p. 46.

27 R. Alexy, 'On the Structure of Legal Principles', 13 Ratio Juris (2000) pp. 294, 296.

28 Ibid., p. 295.

29 Christófolo, supra note 1, p. 246. 
In order to test that claim, one should first consider the definition of legal principles.

Legal principles, as defined by Alexy, are "commands to be optimized"30 that 'comprehend an ideal 'ought' that is not yet relativized to the actual and legal possibilities". ${ }^{31}$ Alexy concedes that there are "cases in which it is not easy to decide whether a norm should be treated as a rule or as a principle". ${ }^{32}$ However, he does make it clear that principles are "the opposite of definitive obligations". ${ }^{3}$

In light of this definition, at least two observations can be made with respect to ius cogens norms. First, there are certainly ius cogens norms that states must comply with "in an 'all or nothing' manner",34 that are "definitive obligations" in the sense that they can "either be fulfilled or not fulfilled, and [their] complete fulfilment is always obligatory". ${ }^{35}$ The ius cogens norm prohibiting torture, for example, is not a "command to be optimized" subject to what is legally and factually possible. Torture is always and completely prohibited. ${ }^{36}$ Similarly, the ius cogens norm prohibiting genocide is not a command that strives for its optimisation, but is rather a very concrete command that is either completely complied with or not at all complied with. The first observation is thus that, on its own terms, Christófolo's arguments in favour of proportionality's utility as a norm conflict resolution mechanism is not applicable to all kinds of ius cogens norms but, at best, to those which one might construe as commands to be optimised. A people's alleged ius cogens right to self-determination, used as an example by Christófolo above, might be one such ius cogens norm since there are multiple degrees and manifestations of self-determination.

But even here, and this is the second observation, problems arise. Christófolo explains that conflicts between ius cogens norms arise, if they arise at all, not at the "abstract level" 37 but "in concreto" 38 and with reference to a particular set of circumstances. But the more concrete a norm becomes (the more it becomes "relativized to the actual and legal possibilities"), ${ }^{39}$ the more likely it is that the norm in question is a rule and not a principle. And if it were a principle, it

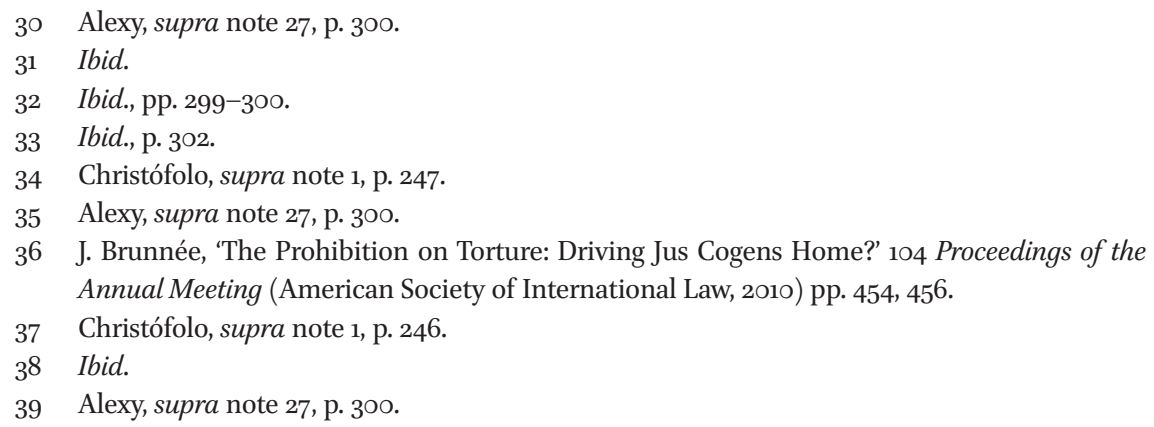


would be, being positioned somewhere on the spectrum between "definitive validity and non-obligation", more general and less likely, in accordance with Christófolo's argument, to generate a norm conflict at all. To illustrate, the general prohibition to acquire territory by force might be a principle and does not conflict with a people's right to self-determination which might also be a principle. This can change, however, if these principles are applied to a concrete situation where a people might desire to sign an agreement that recognises a status quo that was brought about by unlawful force. The process of applying these principles to such a situation will entail a rigorous interpretation of the norms involved, reducing them from their general nature to concrete, deontic obligations, prohibitions or permissions. Proportionality considerations might inform that process. For example, when choosing between different available and equally valid interpretations. However, if such a process of application or concretisation results in the finding of a conflict between the norms thus concretised, proportionality will not be able to resolve such conflicts since norms that might have been principles are now rules. If such a process of application or concretisation leads to a result where both norms can be harmonised, then no conflict existed to begin with.

Thus, even with respect to those ius cogens norms that might be understood as principles, it is questionable whether a proportionality test can play a particularly meaningful role in terms of resolving ius cogens norm conflicts. However, assuming that there could be a small class of situations where ius cogens norms, construed as principles, could generate norm conflicts inter se, the next three sections will seek to show that Christófolo's three arguments in favour of addressing such situations by means of proportionality tests are not entirely convincing.

\subsection{Proportionality Is Necessarily Subjective}

The argument in favour of using proportionality tests to resolve conflicts between ius cogens norms is informed, at least in part, by the conviction that norm conflicts are resolved with reference to "objective and positive criteria ... provided for [by] the legal system itself". ${ }^{40}$ Conflicting norms should be balanced "from the exclusive perspective of international law"41 and "no case would require a rule to be taken from outside the system [of international law] in order to be solved". ${ }^{42}$ In principle, it is difficult to see how this standard of objectivity could be met in circumstances where two ius cogens norms conflict.

40 Christófolo, supra note 1, p. 16.

41 Ibid., p. 251.

42 Ibid., p. 8. 
If a conflict could be answered based on existing, analytical mechanisms of international law, such as the traditional norm conflict resolution principles discussed above or by means of interpreting the conflicting norms in a harmonious manner, then there would not be a conflict of norms in the first place. Indeed, when a system produces a normative conflict, the only way to solve it is to reach beyond the confines of the system that generated the conflict in question. It is one of the benefits of proportionality tests to provide a framework for reaching beyond the existing law in such a manner, but it certainly does so in a subjective manner in the sense that the identity of the legal subject carrying out a proportionality assessment influences the outcome of that very assessment. If it is the case that, as Christófolo argues, ius cogens norm conflicts occur when "ethical plurality placed at the centre of any normative creation process is translated into contradictory commandments", 43 then it is impossible for fundamental, normative conflicts of that kind to be resolved only with reference to the available "normative universe" 44 that is responsible for the existence of such a conflict. In contrast, solving norm conflicts that represent "ethical plurality" must, by necessity, entail ethical value judgments that are subjective.

Even if one argued that a proportionality analysis "is an analytical procedure" 45 and that it does not, in itself, produce substantive outcomes ${ }^{46}$ there are two additional circumstances where the application of proportionality necessarily requires a subjective assessment of the normative relationship between two conflicting norms.

The first situation concerns circumstances where the norms that generated the conflict or where the interest which these norms protect are incommensurable. This is the case when there is no "rationally identified metric for measuring, or scale for 'weighing', the goods and bads in issue". ${ }^{47} \mathrm{Absent}$ an "identified metric" that could guide the process of balancing, there is no objective way to reconcile conflicting norms. For example, where would one find the rational metric with reference to the above-mentioned scenario concerning a people's right to self-determination and the obligation not to recognise the acquisition of territory by unlawful force? On which scale would one, objectively, measure the comparative importance of a people's right to self-determination? It is one

\footnotetext{
43 Ibid., p. 41-42.

44 Ibid., p. 251.

45 A. Stone Sweet and J. Mathews, 'Proportionality Balancing and Global Constitutionalism', 47 Columbia Journal of Transnational Law (2008) p. 76.

46 Ibid.

47 J. Finnis, 'Natural Law and Legal Reasoning', in R.P. George (ed.), Natural Law Theory: Contemporary Essays (Clarendon Press, Oxford, 1992) p. 146 [emphasis in original].
} 
thing if States individually decide how much importance they attach to either of the competing principles ${ }^{48}$ and if these individual decisions bring about a certain state of positive law. It is quite another thing if judicial actors, as agents of the system that produced the conflict, not only make such a decision but also claim that such a decision has the character of an objective determination. This is not necessarily to say that international judicial actors should not at all get involved with deciding norm conflicts when it is not possible to do so based on a commonly and rationally identified metric. However, it is important to acknowledge that such decisions are of a subjective nature.

The second situation when undertaking a proportionality analysis necessarily requires making subjective judgments concerns normative "stalemate[s]"49_ situations of complete equality that proportionality cannot decide, such that a decision maker faces a "dilemmatic or tragic [choice]".$^{50}$ Stalemates may occur seldom, but they do occur. ${ }^{51}$ With respect to domestic systems, it was pointed out that "[ $\mathrm{t}]$ he imperative of peaceful coexistence cannot always tell us which of multiple compromises strikes a better 'balance' between clashing values". 52 Similarly, it has been observed that "[c]onstitutional rights are not a subject-matter, which is so finely distinguished that it excludes structural, that is, real balancing stalemates to such an extent as to make them practically insignificant", ${ }^{33}$ and that courts should defer to the legislature ${ }^{54}$ in such cases. If this is true for domestic law, where the judiciary is an integral part of the domestic legal systems, it is especially true for international law, where judicial institutions possess fewer competences compared to domestic courts, and where conflicts can arise not just within one system but across multiple legal regimes. Therefore, when a norm conflict arises where both norms possess exactly the same importance within the parameters of a given legal regime, proportionality tests will be able to identify how to balance such conflicting norms only at the cost of subjective judicial law-making, thereby exceeding the parameters

48 Kolb, supra note 11, p. 123.

49 V.A. da Silva, 'Comparing the Incommensurable: Constitutional Principles, Balancing and Rational Decision' 31 Oxford Journal of Legal Studies (2011) pp. 273, 292; R. Alexy, A Theory of Constitutional Rights (Oxford University Press, Oxford, 2002) pp. 408, 411; M. Klatt and M. Meister, The Constitutional Structure of Proportionality (Oxford University Press, Oxford, 2012) p. 37.

$50 \quad$ da Silva, supra note 49, p. 292.

$51 \quad$ Alexy, supra note 49, p. 412; M.H. Kramer, 'When Is There Not One Right Answer?', 53 The American Journal of Jurisprudence (2008) pp. 49, 56.

52 D. Wolitz, 'Indeterminacy, Value Pluralism, and Tragic Cases', 62 Buffalo Law Review (2014) pp. 529, 592 .

53 Alexy, supra note 49, p. 411.

54 da Silva, supra note 49, pp. 292, 293, 300. 
of a given legal regime. Accordingly, it has been accepted that proportionality may lead to a "gouvernement des juges" 55 in excess of international judicial actors' competences. It is not certain if a "gouvernement des juges" is the only way to avoid decisions being taken "without rationalization" 56 at all, but it is certain that judicial law-making of that kind could not be justified based on it avoiding subjective decision-making. If it is acknowledged, the necessary subjectivity of proportionality analyses is not necessarily problematic because those whose interests are affected by a particular proportionality analyses are able to critique and to engage with such subjective assessments. If this subjectivity is not acknowledged, however, portraying proportionality tests as objective mechanisms to resolve ius cogens norm conflicts makes it more difficult to distinguish the interests of those who undertake the proportionality analysis from the interests of those whose interests the proportionality analysis affects.

\subsection{Proportionality Does Not Necessarily Safeguard All Interests Concerned}

A crucial benefit of proportionality tests is, according to Christófolo, that their application leaves the "the integrity of the normative universe of ius cogens ... fully valid" ${ }^{77} \mathrm{He}$ explains that proportionality's "optimisation of all applicable norms" 58 can facilitate a legal actor's compliance with all "compulsory commandments ... at least in a partial manner", and that, as a result, the "variety of equally important existing values within the legal system is ... protected".59 Whether proportionality can operate in this manner depends, however, on the divisibility of the interests which a given ius cogens norms protects. In other words, it depends on the possibility of arguing, with reference to a specific norm, that partial, as opposed to full, compliance with that specific norm does not impair that norm's ability to protect a value to which it is linked.

To illustrate, norms that protect a factually indivisible interest are not susceptible to balancing. The most obvious example in this regard is the right to life which protects the factually indivisible interest of life. A person's life cannot be infringed in degrees. The interest of life is either completely, or not at all, protected. In a similar manner, some judges in the Nuclear Weapons Advisory

S.W. Schill and B. Kingsbury, 'Public Law Concepts to Balance Investors' Rights with State Regulatory Actions in the Public Interest - the Concept of Proportionality', in S. Schill (ed.), International Investment Law and Comparative Public Law (Oxford University Press, Oxford, 2010) pp. 102-103.

56 Ibid., pp. 102-103.

57 Christófolo, supra note 1, p. 126.

58 Ibid., p. 50.

59 Ibid., pp. 50, 51. 
Opinion argued that the outright prohibition of nuclear weapons would not constitute a mere limitation of a State's right to self-defence but rather a complete denial of such a right in situations when recourse to a nuclear weapon "was the last available means by way of which the victimized State could exercise its right under Article $5^{1}$ of the Charter". 60 If one accepts, even if only for the sake of argument, that the rights to self-defence (in certain circumstances) and life can protect indivisible interests, the violation of such interests may still be justified or excused ${ }^{61}$ but such a violation will certainly not be susceptible to measurement on a proportionality scale that aims to identify a compromise between two conflicting norms. ${ }^{62} \mathrm{~A}$ compromise presupposes that at least one unit of each of the negotiated interests survives the balancing exercise. Otherwise, there would be no difference between a compromise and the victory of one norm over another. However, that condition is not fulfilled when indivisible interests feature in a proportionality test. Persons proportionately deprived of their right to life are dead. States proportionately deprived of the only means by which they might exercise their right to self-defence are deprived of that right.

The situation might be different with respect to Christófolo's example which concerns the alleged conflict between "the peremptory prohibition of the territorial acquisition" by unlawful force and "the peremptory right of the Palestinian people to self-determination". Here one could argue, with respect to the right to self-determination, that this right could be realised on a spectrum ranging from external independence to local self-governance, or for a certain period in time. The question remains, however, if, in the case of the right to self-determination, such a spectrum represents merely different manifestations of the right or if the spectrum actually reflects different degrees of compliance. If it is the former, then it is not meaningful to speak of a compromise at all. If it is the latter, then there is a risk that the application of proportionality

6o Legality of the Threat or Use of Nuclear Weapons (Advisory Opinion) [1996] ICJ Rep 226 ('Nuclear Weapons'), Separate Opinion of Judge Fleischhauer, para. 3. The extent to which the right to self-defence is indivisible eventually depends, of course, on the specific facts of a given situation and on the extent to which an attack would lead to the partial or complete destruction of a State.

61 See, for example, R. Merkel, '§14 Abs. 3 Luftsicherheitsgesetz: Wann und warum darf der Staat töten?', 62 JuristenZeitung (2007) pp. 373, 377.

62 With respect to the right to life, in particular, there is also the much more fundamental problem regarding the justifiability of a proportionate killing to the person killed, who derives absolutely no benefit from the measure. The argument is essentially that the legitimacy of a measure that results in the extinction of a legal subject cannot be established vis-à-vis that legal subject. See ibid., p. 375 . 
obscures the extent to which the norms that are being balanced are (partially) not complied with.

\subsection{Proportionality Does Not Necessarily Safeguard the Completeness of International Law}

Finally, one of the reasons that Christófolo favours proportionality tests is that the application of proportionality to ius cogens norm conflicts "safeguard[s] the integrity of the international legal system when there are no other applicable and adequate rules for solving legal antinomies ... [by] avoiding a declaration of non liquet" ${ }^{63}$ Subjecting ius cogens norm conflicts to a proportionality analysis ensures international law's completeness by facilitating international law's ability to regulate "any legal relationship" without a judicial agent having to rely on "rule[s] ... taken from outside the system in order to be solved". 64 Essentially, the argument is that proportionality negatively pre-empts non liquet declarations and positively protects international law's completeness by resolving otherwise irresolvable norm conflicts. The negative and positive function of proportionality in this context will be addressed in turn.

With respect to the first argument, Christófolo's concern that irresolvable norm conflicts could invite the issuing of non liquet declarations is not unjustified. Pauwelyn has argued, for instance, that otherwise irresolvable norm conflicts could be addressed by means of a non liquet declaration. ${ }^{65}$ However, as Christófolo himself points out, non liquet declarations respond to legal gaps whereas irresolvable norm conflicts are situations where "more than one norm [is] simultaneously applicable within the system". ${ }^{66}$ Indeed, a finding of non liquet responds to "genuine gaps in the [positive] law",67 to a lack of norms governing matters law "ought to govern". ${ }^{68}$ To borrow the language (and no more than that since the International Court of Justice (ICJ) was not, at least not explicitly, concerned with a ius cogens conflict) of the ICJ's President in the Nuclear Weapons Advisory Opinion, ius cogens norm conflicts, however,

63 Christófolo, supra note 1, pp. 56-57.

64 Ibid., p. 8.

65 Pauwelyn, supra note 5, pp. 152, 419; see also J. von Bernstorff, 'Hans Kelsen on Judicial LawMaking by International Courts and Tribunals: A Theory of Global Judicial Imperialism?', 14 The Law and Practice of International Courts and Tribunals (2015) pp. 35, 49-50.

66 Christófolo, supra note 1, pp. 51-52.

67 G. Hernandez, The International Court of Justice and the Judicial Function (Oxford University Press, Oxford, 2014) p. 249.

68 I. Tammelo, 'On the Logical Openness of Legal Orders: A Modal Analysis of Law with Special Reference to the Logical Status of Non Liquet in International Law', 8 The American Journal of Comparative Law (1959) pp. 187, 192; see also H. Quane, 'Silence in International Law', 84 British Yearbook of International Law (2014) pp. 240, 243. 
constitute a "head-on collision of fundamental principles, neither one of which can be reduced to the other"69 rather than situations where "no ... rule of international law exists".70 It would therefore, as a matter of principle, be inappropriate to respond to ius cogens norm conflicts by means of a non liquet declaration. But this argument rests solely on contemporary principles of international law and is not, as such, an argument in favour of proportionality's ability to pre-empt non liquet declarations. In other words, proportionality has nothing to do with the fact that non liquet cannot be used to decide ius cogens norm conflicts.

The positive element of the argument in favour of proportionality's ability to safeguard the integrity and completeness of international law in turn appears to make two assumptions: first, that the completeness of international law is desirable, and, second, that there is no alternative way of dealing with ius cogens norm conflicts than by subjecting them to a proportionality analysis. The first assumption will be addressed here. The second will form the subject of this contribution's concluding part.

Turning to the first assumption, the completeness of any normative system is not a fact but a stipulation. Accordingly, von Wright acknowledges that the position that of "norm-logical-necessity' normative orders are gapless and free from contradiction" is a position that rests itself on specific "normative ideas".71 Similarly, Luhmann argues that "[t]he world does not provide any guarantee for logical order and consistency of deductions",72 and that legal systems are consistent and complete only to the extent that they themselves stipulate for their own consistency. ${ }^{73}$ This means that Christófolo's argument in favour of proportionality based on proportionality's ability to protect the completeness of international law is only as strong as proportionality's ability to further the normative rationale upon which the stipulation in favour of a complete legal system rests. The conventional rationale in favour of the completeness of international law assumes that an incomplete legal order can lead to legal uncertainty and that it could undermine international law's ability to facilitate the peaceful resolution of disputes. Resolving ius cogens norm conflicts by means of a proportionality analysis serves neither of these objectives and does,

69 Nuclear Weapons, supra note 6o, Declaration of President Bedjaoui, para. 22.

70 The Case of the SS 'Lotus' (France v. Turkey) (Judgment) [1927] Series A No 1023.

71 G.H. von Wright, 'Deontic Logic: A Personal View', 12 Ratio Juris (1999) pp. 26, 33 [emphasis in original].

72 N. Luhmann, Law as a Social System (F. Kastner et al (eds.), K.A. Ziegert (tr.), Oxford University Press, Oxford, 2004) p. 286.

73 Ibid. 
as such, not further the benefits associated with the completeness of international law.

With respect to legal certainty, it has been argued above that in the small class of cases where proportionality could be applied at all (the cases where ius cogens norms could potentially be reconstrued as principles) the application of proportionality is necessarily subjective in the sense that the outcome of the proportionality assessment is linked to the identity of the legal subject undertaking the assessment. This circumstance significantly undermines legal certainty since the outcomes of subjective assessments are difficult to predict. For instance, with respect to Christófolo's example concerning the reconcilability of the "prohibition of the territorial acquisition by forcible means" and the "right of the Palestinian people to self-determination", little is gained in terms of legal certainty from the apparent completeness of international law (achieved by subjecting the conflicting norms to a proportionality analysis) if it is uncertain how the conflict would be resolved. All that is known in such a case is that some decision will be made. And that, to some, might be reason enough to be in favour of deciding ius cogens norm conflicts by means of a proportionality test. Luhmann argues accordingly, that "courts have to decide every case submitted to them" and that the "corresponding norm is called ... the prohibition of the denial of justice". ${ }^{74}$

However, it must be recalled that ius cogens norm conflicts, if they arise at all, arise by definition at the apex of the international legal order and are reflective of an "ethical plurality"75 that informs international law. Each ius cogens norm protects interests of paramount importance ranging from the prohibition of genocide and torture to war crimes, the prohibition of slavery and apartheid. In other words, the stakes connected with ius cogens norm conflicts could hardly be higher. Against that background, it is questionable whether subjective decisions made by judicial actors who, since the law itself does not provide a definitive answer concerning how the interests in question should be balanced, "lack the relevant knowledge, understanding, insights and wisdom for adequate solutions will nevertheless be just". ${ }^{76}$ Indeed, given just how high the stakes are, it could be argued that it might be preferable not to subject ius cogens norm conflicts to a proportionality analysis and to acknowledge the limits of international law's completeness. Sometimes "pointing out deficiencies or gaps in the law (if there are such gaps) might be better than papering

74 Ibid., p. 284.

75 Christófolo, supra note 1, pp. 41-42.

76 J. Stone, 'Non Liquet and the International Judicial Function', in C. Perelman (ed.), Le problème des lacunes en droit (Bruylant, Brussels, 1968) pp. 310-311. 
over the cracks". ${ }^{77}$ Consider the example of a potential conflict between the prohibition of nuclear weapons and a state's right to self-defence. If one accepts, even if only for the sake of the argument, that an irresolvable conflict could arise between these two ius cogens norms (e.g. in circumstances where a nuclear weapon is a state's only means to realise its right to self-defence), then any judicial decision of such a conflict is bound to undermine the integrity of, and respect for international law. If judicial actors would, contrary to the contemporary position of positive international law, merely find that nuclear weapons are always prohibited, respect for such a judicial pronouncement is bound to be limited since it misstates the law. If judicial actors would, contrary to the contemporary position of positive international law, merely find that nuclear weapons can be used in extreme circumstances of self-defence, respect for such a pronouncement would also be limited since it also misstates the law. Offering unequivocal judicial answers to such intricate and fundamentally divisive questions does not provide legal certainty and it does not deliver justice. Subjecting ius cogens norm conflicts to a proportionality analysis can therefore not be justified based merely on the necessity to avoid an incomplete legal order since the application of proportionality to ius cogens norm conflicts undermines the rationale upon which the normative stipulation in favour of a complete legal order is based.

Nonetheless, one might argue that subjecting ius cogens norm conflicts to a proportionality analysis is better than leaving ius cogens norm conflicts unaddressed entirely. That might be correct, but the next and concluding section will try to show that there is an alternative way of addressing ius cogens norm conflicts, which neither requires a proportionality analysis nor the issuing of a non liquet declaration.

\section{Taking ius cogens Norm Conflicts Seriously}

The argument in favour of responding to ius cogens norm conflicts by means of proportionality tests appears to assume that the only alternative to the utilisation of proportionality is to issue a non liquet declaration. However, by way

77 D. Akande, 'Nuclear Weapons, Unclear Law? Deciphering the Nuclear Weapons Advisory Opinion of the International Court', 68 British Yearbook of International Law (1998) pp. 165, 212. Similarly, Lauterpacht argues that at times, "apparent indecision" might "be preferable to a deceptive clarity that fails to give an indication of the inherent complexities of the issue". See H. Lauterpacht, The Development of International Law by the International Court (Cambridge University Press, Cambridge, 1982) p. $15^{2}$. 
of conclusion, this section argues that it is possible to conceive of a method that relies neither on proportionality nor on non liquet declarations, which still takes the problem of ius cogens norm conflicts very seriously and which safeguards the interests of those whose interests a given ius cogens norm conflict affects. In light of the analysis presented in the previous sections, this method should be based, to the largest possible extent, on existing law; it should avoid subjective decisions and provide legal certainty; and it should promote respect for the international rule of law.

All of these objectives can be achieved in the following manner: if faced with an apparent conflict between ius cogens norms, judicial actors should in accordance with their ordinary mandate to apply existing law - attempt to solve such a conflict by means of international law's various norm conflict resolution mechanisms. Such an exercise would include international law's traditional norm conflict resolution principles considered above. And such an exercise might also entail resort to a proportionality analysis. However, if it becomes apparent that the traditional mechanisms are unable to establish a priority between the conflicting norms and if proportionality is inapplicable, because the conflict crystallised between rules and not principles, or because the conflict entails incommensurable or factually indivisible interests or because a genuine "stalemate" exists, judicial actors should declare that a norm conflict exists between two or more simultaneously valid and applicable legal norms that cannot be resolved by international law. Such a declaration should clearly outline the respective norms that are in conflict and communicate that, as a result of the conflict's legal irresolvability, the conduct in question is simultaneously legal and illegal at the same time. For instance, with respect to Christófolo's example concerning the reconcilability of the "prohibition of the territorial acquisition by forcible means" and the "right of the Palestinian people to self-determination" it should, in accordance with the argument presented here, be observed that, if the conflict between those two norms is actually irresolvable, signing the agreement would violate a ius cogens norm and not doing so would equally impair a ius cogens norm. A declaration of this kind would directly reflect the current state of the law and would, as such, be a predictable legal outcome. Moreover, such a declaration would promote respect for the international rule of law since it avoids that judicial actors "overreach" by offering legal answers where none, at least not at present, exist. Such a judicial declaration would of course not definitively decide a given ius cogens norm conflict. However, by confirming unequivocally that an irresolvable conflict exists, such a judicial declaration would give the various stakeholders affected by or connected to a ius cogens norm conflict the chance of engaging with the underlying causes that have triggered the conflict. 
In the Nuclear Weapons Advisory Opinion, the ICJ came close to doing this by encouraging States to reconsider the contemporary legal framework governing nuclear weapons in light of the ICJ s difficulties to decide unequivocally whether or not nuclear weapons could be used in an extreme circumstance of self-defence. ${ }^{78}$ This encouragement is echoed by a reflection towards the end of Christófolo argument in favour of using proportionality to address ius cogens norm conflicts. Christófolo argues that:

[n]obody can reasonably question the importance of finding concrete and timely solutions for avoiding and, most importantly, stopping massacres and gross human rights violations...But one must be careful not to confuse political with legal arguments, regardless of the fact that both deal with inter-subjective relationships and are intrinsically related. ${ }^{79}$

The solution presented in this final section shares Christófolo's conviction. In fact, many of the arguments presented in this contribution are directly derived from the position that applying proportionality to ius cogens norm conflicts leads to a confusion of law and politics. It introduces highly subjective and highly unpredictable elements into the judicial decision-making process. There is no question that there is a need for finding "concrete and timely solutions for avoiding and, most importantly, stopping massacres and gross human rights violations". But in the context of irresolvable ius cogens norm conflicts such solutions cannot be found by judicial actors by means of a proportionality analysis. They are most appropriately found by engaging with those whose interests are directly affected by and/or with those who are directly responsible for the existence of the ius cogens norm conflict.

$78 \quad$ Nuclear Weapons, supra note 6o, para. 98.

79 Christófolo, supra note 1, p. 301. 